Prepared for the U.S. Department of Energy under Contract DE-AC05-76RL01830

\title{
Technology Development Transition Process: Decision-Making Guide and Checklist
}

M Schaeffer M Ace

S Martin

March 2011

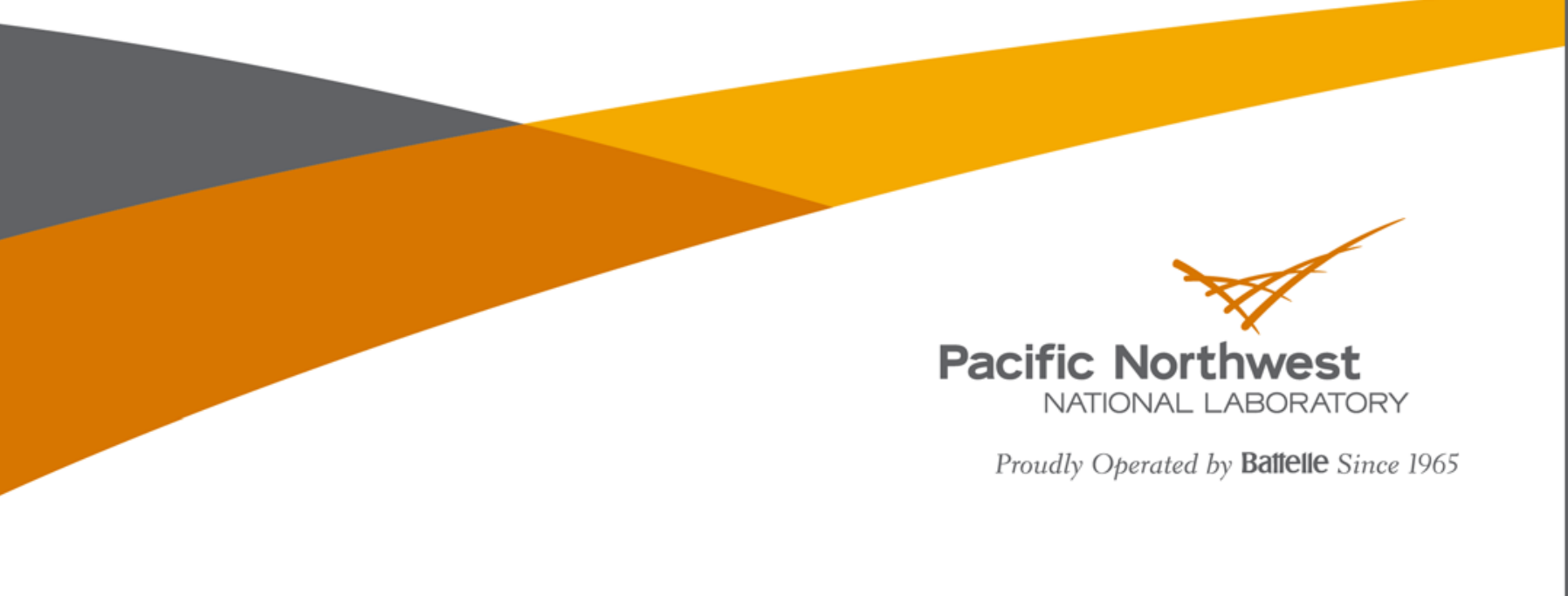




\title{
DISCLAIMER
}

This report was prepared as an account of work sponsored by an agency of the United States Government. Neither the United States Government nor any agency thereof, nor Battelle Memorial Institute, nor any of their employees, makes any warranty, express or implied, or assumes any legal liability or responsibility for the accuracy, completeness, or usefulness of any information, apparatus, product, or process disclosed, or represents that its use would not infringe privately owned rights. Reference herein to any specific commercial product, process, or service by trade name, trademark, manufacturer, or otherwise does not necessarily constitute or imply its endorsement, recommendation, or favoring by the United States Government or any agency thereof, or Battelle Memorial Institute. The views and opinions of authors expressed herein do not necessarily state or reflect those of the United States Government or any agency thereof.

\author{
PACIFIC NORTHWEST NATIONAL LABORATORY \\ operated by \\ BATTELLE \\ for the \\ UNITED STATES DEPARTMENT OF ENERGY \\ under Contract DE-AC05-76RL01830
}

Printed in the United States of America
Available to DOE and DOE contractors from the Office of Scientific and Technical Information,
P.O. Box 62, Oak Ridge, TN 37831-0062;
ph: (865) 576-8401
fax: (865) 576-5728
email: reports@adonis.osti.gov

Available to the public from the National Technical Information Service 5301 Shawnee Rd., Alexandria, VA 22312

ph: (800) 553-NTIS (6847)

email: orders@ntis.gov <http://www.ntis.gov/about/form.aspx>

Online ordering: http://www.ntis.gov 


\section{Technology Development Transition Process: Documentation Guide}

M Schaeffer M Ace

S Martin

March 2011

Prepared for

the U.S. Department of Energy

under Contract DE-AC05-76RL01830

Pacific Northwest National Laboratory

Richland, Washington 99352 


\section{Revisions}

For suggestions regarding documents, processes, and practices associated with this guide, please contact the Technology Development Transition Process team.

\begin{tabular}{|c|c|c|c|}
\hline Rev. No. & Date & Describe Changes & Pages Changed \\
\hline 0 & $3 / 1 / 2011$ & Original document approved in ERICA & N/A \\
\hline & & & \\
\hline & & & \\
\hline & & & \\
\hline
\end{tabular}




\section{Acronyms and Abbreviations}

$\begin{array}{ll}\text { CONOPS } & \text { concept of operations } \\ \text { COTS } & \text { commercial off the shelf } \\ \text { DOD } & \text { Department of Defense } \\ \text { MRL } & \text { manufacturing readiness level } \\ \text { PI } & \text { principal investigator } \\ \text { PM } & \text { project manager } \\ \text { PMP } & \text { project management plan } \\ \text { PNNL } & \text { Pacific Northwest National Laboratory } \\ \text { TDTP } & \text { technology development and transition plan } \\ \text { TRL } & \text { technology readiness level }\end{array}$




\section{Contents}

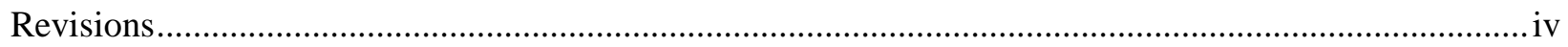

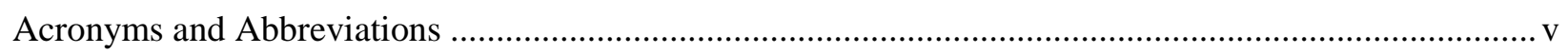

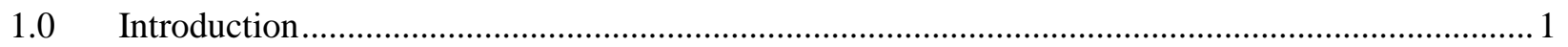

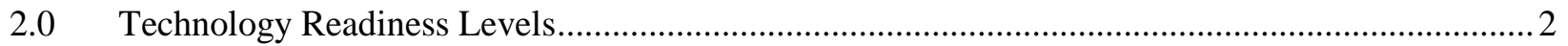

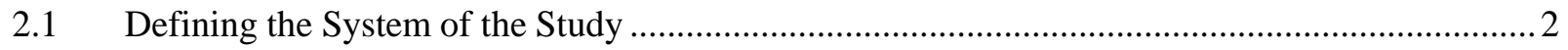

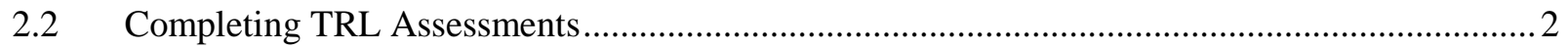

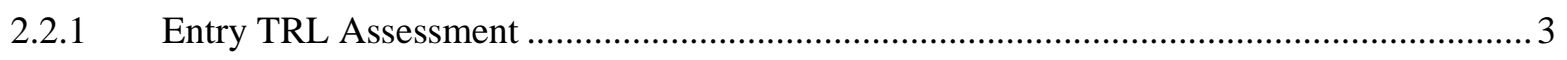

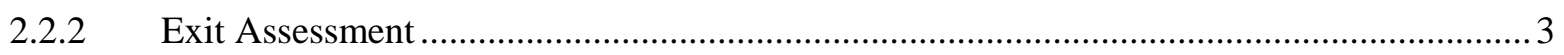

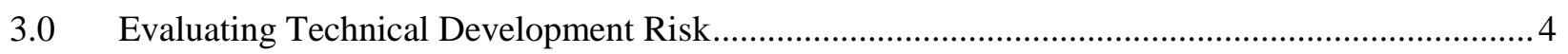

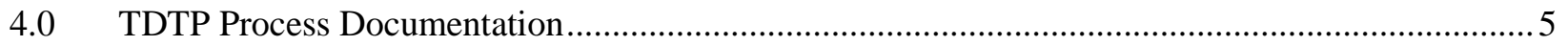

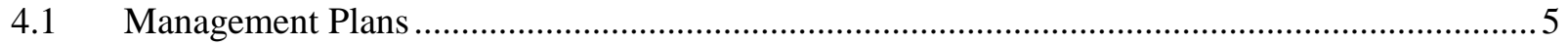

4.1.1 Project Management Plans ............................................................................................... 5

4.1.2 Mission Needs Statements …........................................................................................ 5

4.1.3 System Engineering Management Plans ........................................................................... 5

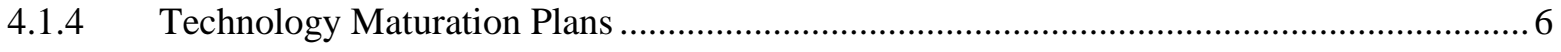

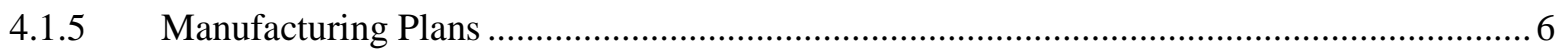

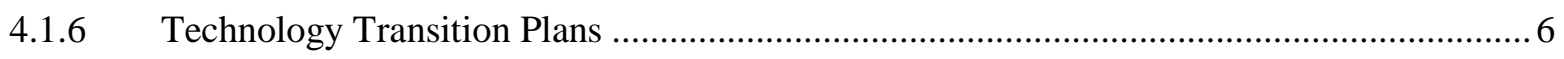

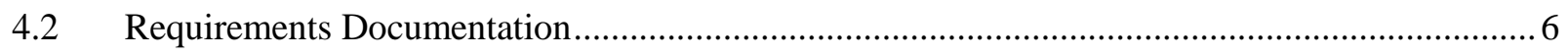

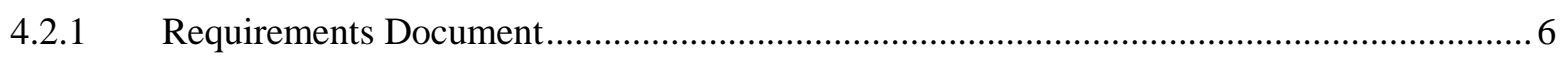

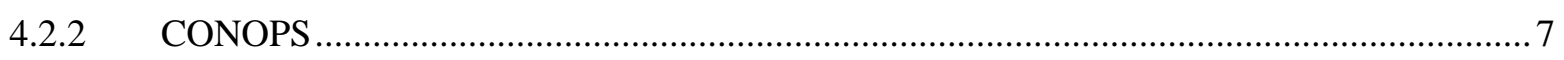

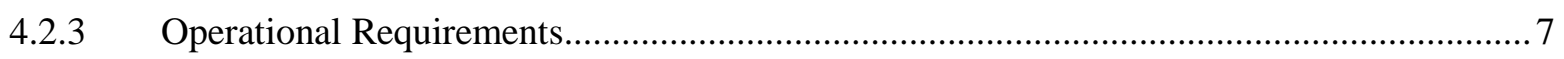

4.2.4 System Requirements Specifications ....................................................................... 7

4.2.5 Subsystem Requirements Specifications................................................................ 7

4.2.6 Interface Requirements Specifications................................................................. 7

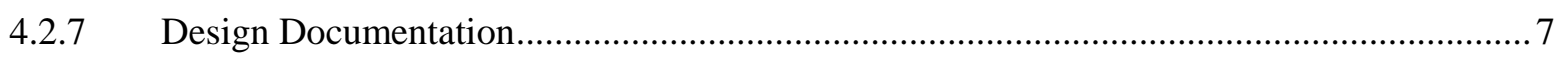

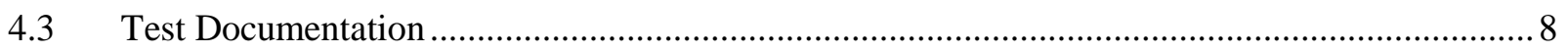

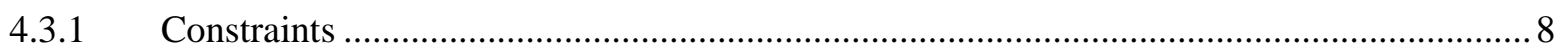

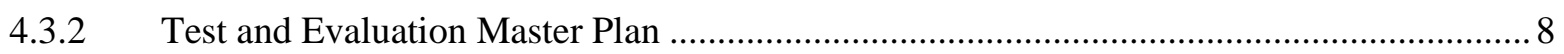

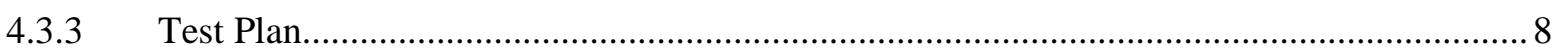

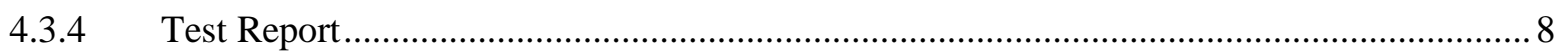

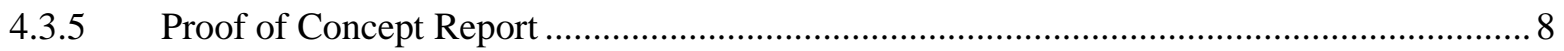

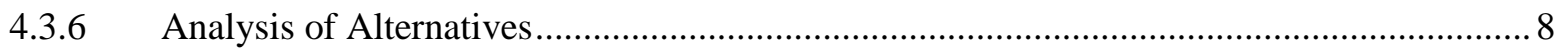

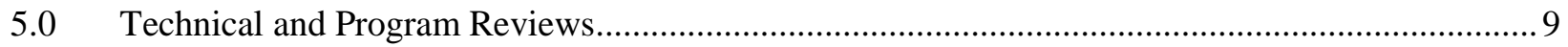




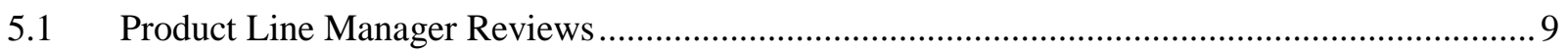

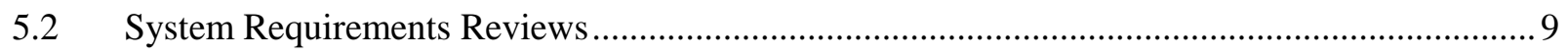

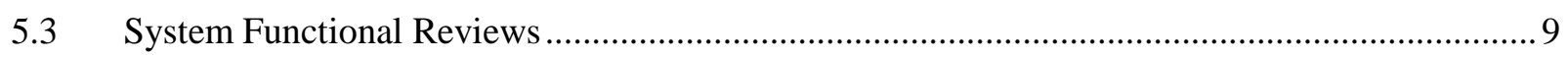

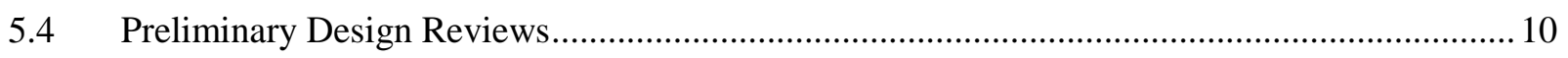

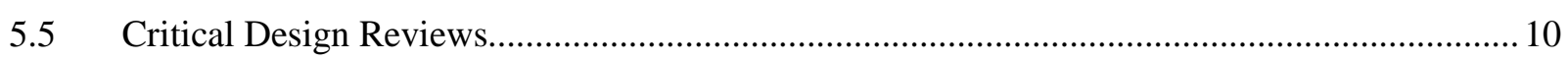

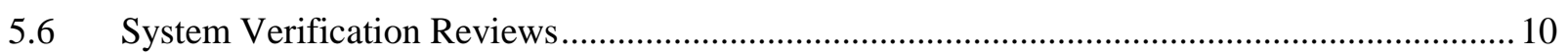

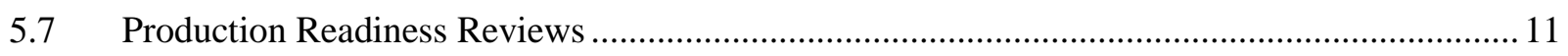

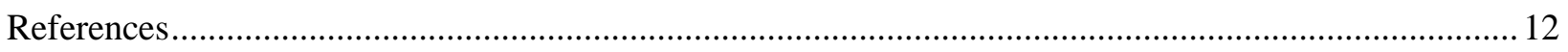

Appendix A. Documentation and Review Checklist and TRL Assessment ............................................ 13

Appendix B. TDTP Documentation and Review Timing.................................................................... 15

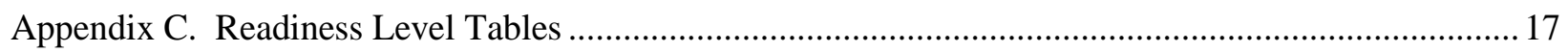

\section{Tables}

Table 1. Documentation and Review Checklist.............................................................................. 13

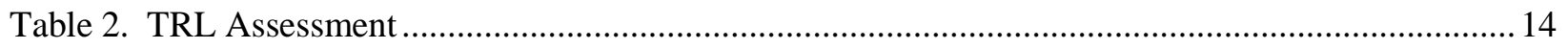

Table 3. Documentation and Reviews for Low-Risk, Less-Complex Projects......................................... 15

Table 4. Documentation and Reviews for Higher-Risk, More-Complex Projects.................................... 16

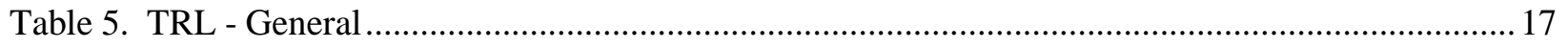

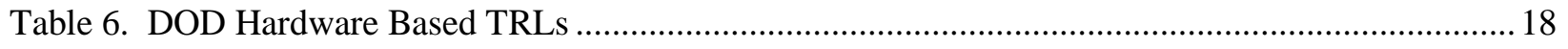

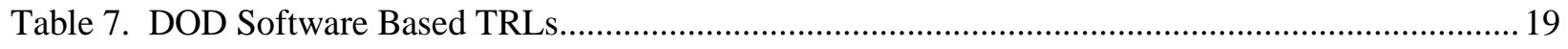

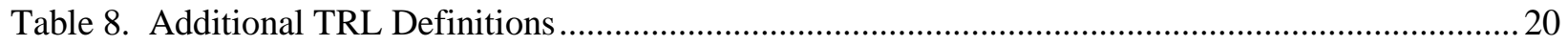

Table 9. Manufacturing and Technology Readiness Levels ................................................................. 21 


\subsection{Introduction}

Planning for and achieving the right level of documentation for projects is consistent with the Laboratory's aims for securing greater success and external reputation for technology development and systems engineering projects. This increased level of planning also supports the completion of projects with more predictable results, fewer surprises, and greater alignment with the end user and application of the technology.

This guide and its documentation and review checklist (Appendix A) are intended to assist the product line manager and project manager (PM)/principle investigator (PI) assess the right level of product line oversight and project documentation requirements for each technology development and transition project (TDTP). Appropriate documentation practice demonstrates Pacific Northwest National Laboratory's (PNNL’s) application of standards for technology development and the capability to replicate and document its systems engineering and technology development research.

The intent of the proposal checklist is to record agreement for deliverables and hold points for intermediate reviews. Determining the "right sized" product line oversight and technical support documentation is based on the consideration of project technical risk and complexity. If both factors are low, then minimal oversight and documentation may be sufficient. If risk or complexity is high, then greater oversight and technical documentation are warranted — if both are high, it is a necessity. Appendix B provides examples of levels of documentation and review for projects with low risk and complexity as well as for those with high risk and complexity.

Explicit client expectation of documentation and oversight is another factor-a client may have provided input concerning documentation and process expectations. Additionally, prior experience with the client may also provide insight into the expectations for rigor in documentation and oversight. The $\mathrm{PM} / \mathrm{PI}$ should anticipate and list all documentation, technical, and programmatic reviews that are likely to be expected by the client. 


\subsection{Technology Readiness Levels}

Technology readiness levels (TRLs) serve as the coordinates by which a project's progress can be mapped. TRLs are assessed by:

- the tangible attributes of the system, which are an examination of prototype testing and demonstrated performance in a defined environment

- the system's supporting documentation, which is an examination of current documentation as supporting evidence of the readiness of the technology and its replication.

While the prototype maturity criteria remain essentially consistent from agency to agency and are defined almost identically by each agency's version of technology readiness, the documentation expected can vary substantially from agency to agency.

Before engaging the product line manager, PM/PIs need to assess the maturity of a proposed system and the intended maturity of the delivered product. This is to help all Laboratory stakeholders clearly understand the scope of work required for a project and the amount of risk involved.

Appendix C provides several definitions for TRLs, including the general and specific definitions for hardware versus software projects. TRLs are closely related to manufacturing readiness levels (Appendix C), which can be evaluated in a similar fashion. While manufacturing readiness levels are not documented for TDTP purposes, they can be used as another lens through which to examine a project before meeting with the product line manager. Manufacturing readiness levels may be important for a project expected to transition into production.

If applicable, be sure to evaluate the project's previous Laboratory work. Select a definition from the table in Appendix B that best describes the level of testing, integration, and documentation achieved.

\subsection{Defining the System of the Study}

Some projects may be scoped to develop technology that is destined to be a component of a much larger system. Other projects may be scoped to create the larger system, either by developing and integrating technology or by integrating commercial off-the-shelf (COTS) technology in a novel way. To properly assess TRLs, the PM/PI should consider the new technology in the context of the eventually deployed or manufactured system.

\subsection{Completing TRL Assessments}

TRLs will be discussed at the proposal meeting by the project line manager and the PI/PM. Understanding a project's level of development in terms of entry and exit TRLs will help right size the project's documentation rigor.

TRL assessments, in general, apply to technology incorporated into a component or subsystem. If a project has only one new technology element, then the assessment should apply to prior work with that element. If a project uses multiple new technologies, then each should be assessed. However, clients and others tend to want an overall assessment. 


\subsubsection{Entry TRL Assessment}

The approach chosen to complete an entry TRL assessment must be tailored to the size and complexity of the project. One example is the approach described in Bilbro (2007), which is to define the overall TRL as equal to the least mature subsystem or component TRL. This approach is the easiest to defend and is a good choice when a project has only one or two new technology elements.

For U.S. Department of Defense (DOD) clients, technology readiness assessment models address specific components or subsystems with critical technology elements independently. A component is considered critical if it is:

- $\quad$ necessary for the system to be able to perform its function and is new and novel

- a reused element from other mature systems but was originally developed for use in a different operational environment.

In cases where the project prototype will demonstrate multiple new technologies, or where the prototype is expected to transition beyond TRL6 in essentially the same configuration, it may make sense to apply a system readiness level approach. Sauser et al. (2006) evaluates a system's overall readiness level by evaluating each component's TRL and their component-to-component integration level as a measure of the system's TRL. The United Kingdom's Ministry of Defense provides a graphical means of depicting composite readiness that would fit well with the DOD's critical technology readiness assessment methodology.

For internal assessments of TRLs, the PM should determine the most appropriate method to evaluate the TRL for each critical technology to be developed, based on prior work. Be sure to limit the inquiry to those critical technologies that are expected to transition beyond TRL6 into the client's final system; do not consider elements that exist only to support the demonstration, such as computer-in-the-loop control systems or temporary housings. Regardless of the method, PMs must identify each critical technology at the subsystem level, determine the level of integration represented by that subsystem, and describe the most severe test environment that the technology has been subjected to. Then consider the technology from the prior project and select a definition from the table in Appendix B that best describes the level of testing, integration, and documentation achieved.

The Air Force Research Laboratory has developed a spreadsheet-based TRL assessment tool called the TRL Calculator, which can be accessed on the Technology Development and Transition webpage. This tool has built-in training documentation and allows a team to assess and track TRL maturity by answering a range of questions.

\subsubsection{Exit Assessment}

Consider the intention for the proposed project and select the TRL that represents the expected end point for the project as defined by completeness of the prototype, testing it will be subjected to, and the client's expectations for documentation. While entry TRLs may be difficult to assess with multiple technologies at different levels, exit TRL should be easier to assess. If the end goal for the project is to demonstrate all technology elements in a system-scale prototype in an operating environment, then all technologies will reach TRL6. 


\subsection{Evaluating Technical Development Risk}

For the proposal meeting with the product line manager, PMs should be prepared to discuss any project-specific technical risks, such as:

- $\quad$ multiple components with TRLs 1 through 5

- $\quad$ significant development to be completed by a subcontractor

- significant performance that is contingent upon a component or part (such as a prototype that will not function, introducing an additional development cycle).

Consider the technical complexity of the system prototypes. A simple project to develop a selfcontained component that requires only two or three science and engineering disciplines may have limited development risk but greater integration risk if the component is a part of the client's larger system. A more complex project might include a complete system encompassing many science and engineering specialties involving multiple new technology development risks.

As appropriate, the PM/PI should also consider developing test strategies and anticipate difficulty in handling specific materials needed for the project. Other considerations should include the client's expectation of final prototype maturity. 


\subsection{TDTP Process Documentation}

The TDTP process provides a means for product line management to review a project's progress against its schedule and goals. Project documentation is central to the TDTP process and will be a significant topic during the proposal meeting. To determine and record the appropriate level of documentation for a project, the product line manager and PM/PI will complete the checklist in Appendix A. To promote a consistent understanding, document descriptions are provided below.

\subsection{Management Plans}

\subsubsection{Project Management Plans}

Project management plans (PMPs) are to be written for all PNNL projects. Guidance and exhibits for PMP development can be found in the Develop and Approve Project Management Plan subject area in How Do I ...? For less-complex, lower-risk projects, the PMP introduction may include a mission needs statement, a systems engineering management plan, a technology maturation plan, a manufacturing plan, and a technology transition plan. Complex projects with higher risk may benefit from having some or all of this content included in separate documents.

For a simple and lower risk TDTP, the technical approach section of the PMP should include a description and timeline for any documentation deliverables that have been identified by the product line manager, as recorded in the checklist included in Appendix C. The documents will likely include a formal requirements document, test and evaluation plans and report, and complete design documentation at the least.

For projects with a combined project management plan, the technical approach section should also describe the planned evolution of prototypes from simple proof of concept models to the final demonstration prototype, and each version in between. Each round of prototype described should include a clear definition of the design intent and the functions implemented at that stage, the number of units to be built, and the planned testing to be performed.

\subsubsection{Mission Needs Statements}

Mission needs statements, also known as the initial capabilities document in DOD, describe the highlevel need for specific functional capabilities required to accomplish mission objectives. Note that while this information is written as an overview, it should still convey the value of the capability. Sufficient background investigation should be undertaken to make sure that the need is not already fulfilled by an existing or planned capability. This information will normally be included in the PMP, but complex system integration documents may benefit from developing a stand-alone mission needs statement.

\subsubsection{System Engineering Management Plans}

Systems engineering management plans describe the intended use of the system engineering process throughout the project. The intended system engineering documents to be developed during the project are explained in detail (as indicated on the documentation and review checklist in Appendix A). Systems 
engineering management plans also describe the intended formal design and project reviews_-including intent, attendees, and protocol — to be conducted during the project. This information can be included in the PMP in less complex and lower risk projects.

\subsubsection{Technology Maturation Plans}

Technology maturation plans describe the overall system design concept, define the TRL for each main component, and delineate each design cycle. There can be multiple design cycles planned before progressing to the next TRL. For each cycle, technology maturation plans describe the design intent, number and make-up of prototypes, TRL of each component and of the system at exit of the step, and the high-level testing intent. This information can be included in the PMP in less complex and lower risk projects.

\subsubsection{Manufacturing Plans}

During the design phases, PMs should consider what may be required if the project develops to manufacturing or if PNNL chooses to license the technology to a vendor. It reduces costs associated with the technology transition, and it minimizes a vendor's complications related to redesign.

Manufacturing plans describe the manufacturing organization, methods, and needed resources for a TRL6 prototype or TRL7 or greater product. Details for this description include the resource training plan, tooling or special equipment required, expected capacity and throughput, manufacturing risks, component "make/buy" decisions, and subcontractor management plans. A less complex and lower risk project that requires manufacturing planning may include this information in the PMP. Complex, higherrisk projects with significant prototype needs and projects requiring design for manufacturability should develop a stand-alone document.

\subsubsection{Technology Transition Plans}

Technology transition plans describe the final stage of technology development. Details should include expected outcomes of the project, funding strategy for transition (source, amount, and timing), later development schedule and milestones, and transition or hand-off information (which should note the transition or hand-off schedule, identification of the "customer," risk assessment, acquisition strategy, and integration plan). A less complex, lower risk project that requires technology transition planning may include this information in the PMP. Complex, higher risk projects and projects with a technology transfer task should develop a stand-alone document.

\subsection{Requirements Documentation}

\subsubsection{Requirements Document}

For simple, low-risk projects, a single requirements document may be adequate to describe the developed technology's functional and performance attributes. A simple requirements document includes sections describing the concept of operations (CONOPS), operational requirements, system-level functional and performance requirements, and subsystem-level requirements. For complex, high-risk 
projects or for projects whose clients request extensive requirements documentation, this information should be presented in stand-alone documents.

\subsubsection{CONOPS}

Whether written as a stand-alone document or as a section of a single requirements document, the CONOPS describes the end user's operation, defines the operational environment, and describes the solution in place today and the desired benefits from a supposed replacement system.

\subsubsection{Operational Requirements}

Operational requirements define the required outcomes from the new system in a qualitative fashion. For DOD, operational requirements are found in capability development documents and capabilities production documents.

\subsubsection{System Requirements Specifications}

System requirements specifications provide the quantitative description of the functional requirements - a qualitative description of what the system does—as well as performance requirements, also known as nonfunctional requirements, which are quantitative requirements of system performance indicating how and how well the system performs functions. A finalized version of system requirements specifications should be completed after final testing.

\subsubsection{Subsystem Requirements Specifications}

Functional and performance attributes for a subsystem are defined by subsystem requirements specifications. For example, projects with specific software needs may define them in a software requirements specification.

\subsubsection{Interface Requirements Specifications}

Interface requirements specifications describe the operational, functional, performance, and protocol requirements that pertain to the interfaces between subsystems. For most projects, these requirements can be included in other documents, but this document may be appropriate when the interfaces are complex. Though primarily concerned with software interfaces, the format can also apply to hardware and human interfaces.

\subsubsection{Design Documentation}

Maintained throughout the development of each round of prototype, the design documentation consists of sketches, drawings, schematics, bills of material, component specifications, operation manuals, assembly instructions, software source and compiled code, and other related documentation. 


\subsection{Test Documentation}

\subsubsection{Constraints}

Typically developed prior to TRL1, a constraints document describes the experimental, business related (funding, client, etc.), and conceptual constraints that channeled a researcher's inquiry into specific directions. This document may be useful to integrate multiple explorations of similar technologies into application solutions and may form the starting point for content found in operational requirements documents.

\subsubsection{Test and Evaluation Master Plan}

The test and evaluation master plan, also called the test strategy, documents the overall structure and objectives of the test and evaluation program. It provides a framework to generate detailed test and evaluation plans, and documents schedule and resource implications associated with the test and evaluation program, particularly important when multiple PNNL and client organizations are involved. This plan identifies the test and evaluation necessary during developmental and operational test phases, and allocates parameters to be verified across multiple test units to be tested during the project.

Note that if the test and evaluation master plan is required by the client, it will duplicate some content from the technology maturation plan and project schedule.

\subsubsection{Test Plan}

Test plans identify the tests to be performed, functions and performance elements to be tested, personnel responsible for each task, and technical risks that can be addressed through that level of testing. Test plans may include descriptions of the test objective, functions/features to be tested, acceptance criteria, testing tools and techniques, test schedule, test environment, and risks and contingencies.

\subsubsection{Test Report}

Test reports restate elements of the test plan, provide test data taken during the test, describe analysis applied to the data, summarize analyzed data into meaningful statements, and provide conclusions that can be drawn from the data.

\subsubsection{Proof of Concept Report}

A proof of concept report is prepared at the end of the proof of concept phase. It describes the experimentation, testing, and analysis conducted to assert proof of concept viability.

\subsubsection{Analysis of Alternatives}

An analysis of alternatives describes the systematic and analytical decision-making process used by the PM/PI to identify the optimal method of satisfying the mission need through the project. An analysis of alternatives involves the use of trade studies that evaluate effectiveness, suitability, and lifecycle cost for each viable alternative (those that fulfill the mission need and align with the concept of operations). 
For some projects, the alternatives might be different configurations of COTS technology components that PNNL could architect into a system. For other projects, the alternatives might include developing new technology, initially considered a fit to meet the mission need, versus using other technology or COTS components instead.

\subsection{Technical and Program Reviews}

Reviews can be completed in several ways: they can be counted as project documents that are completed by the PM and delivered to the product line manager, or they can be presentations with datasheets that are delivered to the product line manager or client. Note that clients define specific reviews and protocols as part of the statement of work. The product line manager may add additional review schedules depending on a variety of project factors.

\subsection{Product Line Manager Reviews}

Product line managers determine the reviews that are needed on their projects based on the project risk level and other factors (e.g., customer sensitivities or PM experience). These reviews can occur at any point during the project based on risk, client, and other factors; often, product line manager reviews occur during the proposal stage, project initiation, project execution, and closeout. Reviews can be conducted on the project as a whole, on parts of larger projects, or on deliverables. In accordance with project-specific requirements, project review questions will be asked to confirm whether requirements are being followed.

\subsection{System Requirements Reviews}

System requirements reviews are a multidisciplinary technical review to verify that the system under review can proceed into initial systems development. These reviews also verify that all system operational requirements derived from the mission needs statement (initial capabilities document) and the operational requirements document are defined, testable, and consistent with cost, schedule, risk, technology readiness, and other system constraints. System requirements reviews are intended to confirm that the user's operational requirements are sufficiently well understood to establish an initial systemlevel requirements baseline. Note at this stage that the developer asserts understanding of the required system outcomes without necessarily understanding all of the functions the system will perform.

\subsection{System Functional Reviews}

System functional reviews are multidisciplinary reviews that verify the system's functional baseline is established and has a reasonable expectation of satisfying the operational requirements within the budget and schedule. The developer now understands not only the system requirements, but also the functions the system will perform to achieve those requirements. Definitions of the items or elements below the system level are fully defined in this document. This review contrasts the composition of a subsystem against the system's functional specifications. 


\subsection{Preliminary Design Reviews}

Preliminary design reviews establish the baseline of subsystems and components of the system (including hardware, software, and human/support systems) and underlying architectures to verify that the system under review has a reasonable expectation of satisfying the requirements within the budget and schedule. This review assesses the allocated design captured in subsystem product specifications for each subsystem (hardware and software) and ensures that each function in the functional baseline has been allocated to one or more subsystems. Subsystem specifications for hardware and software, along with the associated interface requirements specification, enable detailed design or procurement of subsystems.

For complex systems, a preliminary design review may be conducted incrementally for each subsystem. These incremental reviews lead to a system-level preliminary design review. A preliminary design review report should be distributed following the review to address the reviewer's inputs. A preliminary design review is most likely to be required on projects with TRL7 level deliverables or on projects whose clients expect a minor update from TRL6 to TRL7.

\subsection{Critical Design Reviews}

The critical design review is a multidisciplinary technical review establishing the initial product baseline to verify the system has a reasonable expectation of satisfying the requirements of the operational requirements document (or capability development document) and the system requirements within the budget and schedule. Incremental reviews may be held for each subsystem culminating with a system-level critical design review. This review assesses the final design as captured in product specifications for each subsystem and ensures that each product specification has been captured in detailed design documentation.

Product specifications for hardware enable the fabrication of components and subsystems and include production drawings. Product specifications for software enable coding of the computer software modules. The critical design review evaluates the proposed baseline ("build-to" documentation) to determine if the design documentation (initial product baseline including item detail, material, and process specifications) is satisfactory to start initial manufacturing. A review is most likely to be required on projects with TRL7 deliverables or for those clients expecting a minor update from TRL6 to TRL7.

\subsection{System Verification Reviews}

The system verification review is a multidisciplinary product and process assessment to verify that the system can proceed into low-rate initial production and full-rate production within cost (program budget), schedule (program schedule), risk, and other system constraints. System verification reviews establish and verify final product performance. System verification reviews are often conducted concurrently with production readiness reviews. A functional configuration audit (verifying that actual performance complies with design and interface requirements) may also be conducted concurrently with the system verification review, if desired. The review is most likely to be required on projects with TRL6 or TRL7 deliverables or for those clients expecting a minor update from TRL6 to TRL7. 


\subsection{Production Readiness Reviews}

Production readiness reviews assess a program to determine if the design is ready for production and if the prime contractor and major subcontractors have accomplished adequate production planning without incurring unacceptable risks. The review examines risk to determine if production or production preparations identify unacceptable risks that might breach thresholds of schedule, performance, cost, or other established criteria. The review evaluates the full, production-configured system to verify that it correctly and completely implements all system requirements and determines whether traceability of final system requirements to the final production system is maintained. Production readiness reviews are most likely to be required only on projects with TRL7 level deliverables, where PNNL is expected to be the manufacturer of record. 


\section{References}

J.W. Bilbro, Systematic assessment of the program/Project Impacts of Technological Advancement and Insertion Revision A, JB Consulting International, Huntsville, AL, 2007.

Sauser B, V Dinesh, J Ramirez-Marquez, and R Gove. 2006. "From TRL to SRL: The Concept of Systems Readiness Levels.” In Conference on Systems Engineering Research. Aerospace Corporation. Accessed November 11, 2010 at http://sse.stevens.edu/fileadmin/cser/2006/papers/126-SauserTRL\%20SRL.pdf.

United Kingdom Ministry of Defense. 2010. “AOF - Technology Management - Applying System Readiness Levels (SRLs).” UK MOD Defense Acquisition, version 1.0.5. Accessed November 11, 2010 at http://www.aof.mod.uk/aofcontent/tactical/techman/content/srl_applying.htm. 


\section{Appendix A. Documentation and Review Checklist and TRL Assessment}

Table 1. Documentation and Review Checklist

\begin{tabular}{|c|c|}
\hline \multicolumn{2}{|c|}{ Project Management Plan } \\
\hline \multicolumn{2}{|c|}{ Select either the combined project management plan in one document } \\
\hline & $\begin{array}{l}\text { Combined Project Management Plan (which includes components from the mission needs statement, } \\
\text { technology maturation plan, and system engineering management plan.) }\end{array}$ \\
\hline \multicolumn{2}{|r|}{ or the stand-alone PMP and the documents selected from the following list: } \\
\hline & Stand-alone Project Management Plan plus the following stand-alone documents: \\
\hline & Mission Needs Statement \\
\hline & System Engineering Management Plan \\
\hline & Technology Maturation Plan \\
\hline & Manufacturing Plan \\
\hline & Technology Transition Plan \\
\hline \multicolumn{2}{|c|}{ Requirements Documentation } \\
\hline \multicolumn{2}{|c|}{ Select either the combined requirements document } \\
\hline & $\begin{array}{l}\text { Combined Requirements Document (which includes components from ConOps, operational } \\
\text { requirements, functional requirements, performance requirements, interface requirements, etc.) }\end{array}$ \\
\hline \multicolumn{2}{|c|}{ or separate documents from the following list: } \\
\hline & CONOPS \\
\hline & Operational Requirements \\
\hline & System Requirements Specification \\
\hline & Subsystem Requirements Specification \\
\hline & Interface Requirements Specification \\
\hline \multicolumn{2}{|c|}{ But in all cases must complete } \\
\hline & Design Documentation \\
\hline \multicolumn{2}{|c|}{ Test Documentation } \\
\hline \multicolumn{2}{|c|}{ Complete the documents selected from the following list: } \\
\hline & Test and Evaluation Master Plan \\
\hline & Constraints (TRL1 only) \\
\hline & Test Plan (per phase) \\
\hline & Test Report (per phase) \\
\hline & Proof of Concept Report (TRL3) \\
\hline & Analysis of Alternatives \\
\hline \multicolumn{2}{|c|}{ Formal Reviews } \\
\hline \multicolumn{2}{|c|}{ Complete the reviews selected from the following list: } \\
\hline & Product Line Manager Review \\
\hline & System Requirements Review \\
\hline & System Functional Review \\
\hline & Preliminary Design Review \\
\hline & Critical Design Review \\
\hline & System Verification Review \\
\hline & Production Readiness Review (TRL7) \\
\hline
\end{tabular}


Table 2. TRL Assessment

\begin{tabular}{|c|c|c|c|}
\hline $\begin{array}{l}\text { Current } \\
\text { TRL(s) }\end{array}$ & $\begin{array}{c}\text { Ending } \\
\text { TRL }\end{array}$ & $\begin{array}{c}\text { Technology Readiness } \\
\text { Level }\end{array}$ & System Maturity \\
\hline & & $\begin{array}{l}\text { 1. Basic principles } \\
\text { observed and reported }\end{array}$ & $\begin{array}{l}\text { None: pure scientific experimentation. Analytical (paper } \\
\text { study, computer or mathematical model) research or simple } \\
\text { studies of basic properties in a laboratory setting. }\end{array}$ \\
\hline & & $\begin{array}{l}\text { 2. Technology concept } \\
\text { and/or application } \\
\text { formulated }\end{array}$ & $\begin{array}{l}\text { None: examples are limited to paper studies. Application } \\
\text { fit analysis. }\end{array}$ \\
\hline & & $\begin{array}{l}\text { 3. Analytical and } \\
\text { experimental critical } \\
\text { function and/or } \\
\text { characteristic proof of } \\
\text { concept }\end{array}$ & $\begin{array}{l}\text { Nonscale individual components developed from the new } \\
\text { technology are supported by laboratory apparatus and } \\
\text { instrumentation. Analytical studies and demonstration of } \\
\text { nonscale individual components. }\end{array}$ \\
\hline & & $\begin{array}{l}\text { 4. Component and/or } \\
\text { breadboard; validation } \\
\text { in laboratory } \\
\text { environment }\end{array}$ & $\begin{array}{l}\text { Integration of nonscale components in a low-fidelity } \\
\text { breadboard to show pieces will work together in laboratory } \\
\text { setting. Not fully functional and does not have completed } \\
\text { form or fit but representative of technically feasible } \\
\text { approach suitable for intended application. }\end{array}$ \\
\hline & & $\begin{array}{l}\text { 5. } \text { Component and/or } \\
\text { breadboard validation in } \\
\text { relevant environment }\end{array}$ & $\begin{array}{l}\text { Higher fidelity breadboard is functionally equivalent but not } \\
\text { necessarily form (size) and/or fit (interface). Should be } \\
\text { approaching appropriate scale. May include integration of } \\
\text { several components with reasonably realistic support } \\
\text { elements/subsystems to demonstrate functionality in a } \\
\text { laboratory setting with simulated operational environment. }\end{array}$ \\
\hline & & $\begin{array}{l}\text { 6. System/subsystem } \\
\text { model or prototype } \\
\text { demonstration in a } \\
\text { relevant environment }\end{array}$ & $\begin{array}{l}\text { Representative model or prototype system; very close to } \\
\text { form, fit, and function of operational system; tested in a } \\
\text { relevant environment. Examples include demonstration of } \\
\text { fully functional prototype in a high-fidelity laboratory or } \\
\text { simulated operational environment. }\end{array}$ \\
\hline & & $\begin{array}{l}\text { 7. System prototype } \\
\text { demonstration in an } \\
\text { operational environment }\end{array}$ & $\begin{array}{l}\text { Prototype is near or at planned operational system. } \\
\text { Demonstration of actual system prototype in operational } \\
\text { environment. }\end{array}$ \\
\hline
\end{tabular}

Proposal Manager:

Date:

Product Line Manager:

Date: 


\section{Appendix B. TDTP Documentation and Review Timing}

Table 3. Documentation and Reviews for Low-Risk, Less-Complex Projects

\begin{tabular}{|c|c|c|c|c|c|c|}
\hline & TRL1 & TRL2 & TRL3 & TRL4 & TRL5 & TRL6 \\
\hline $\begin{array}{l}\text { Management } \\
\text { Plans }\end{array}$ & $\begin{array}{l}\text { May } \\
\text { provide a } \\
\text { journal } \\
\text { article as } \\
\text { the } \\
\text { feasibility } \\
\text { report }\end{array}$ & $\begin{array}{l}\text { May be a } \\
\text { journal article } \\
\text { or proposal } \\
\text { for work }\end{array}$ & $\begin{array}{l}\text { PMP } \\
\text { (including } \\
\text { description of } \\
\text { mission need } \\
\text { and detailed } \\
\text { technical } \\
\text { approach } \\
\text { section) }\end{array}$ & & & \\
\hline Requirements & & & $\begin{array}{l}\text { Begin to draft } \\
\text { requirements } \\
\text { document }\end{array}$ & \begin{tabular}{|l|} 
Requirements \\
documentation, \\
including \\
description of \\
concept of \\
operations \\
\end{tabular} & $\begin{array}{l}\text { Design } \\
\text { documentation }\end{array}$ & $\begin{array}{l}\text { Design } \\
\text { documentation }\end{array}$ \\
\hline Test & & & & \begin{tabular}{|l|} 
Test plan and \\
subsequent test \\
report
\end{tabular} & \begin{tabular}{|l|} 
Test plan and \\
subsequent test \\
report
\end{tabular} & $\begin{array}{l}\text { Test plan and } \\
\text { subsequent test } \\
\text { report }\end{array}$ \\
\hline \begin{tabular}{|l|} 
Formal \\
Reviews
\end{tabular} & \multicolumn{6}{|c|}{ At discretion of product line manage } \\
\hline
\end{tabular}


Table 4. Documentation and Reviews for Higher-Risk, More-Complex Projects

\begin{tabular}{|c|c|c|c|c|c|c|}
\hline & TRL1 & TRL2 & TRL3 & TRL4 & TRL5 & TRL6 \\
\hline \multirow[t]{5}{*}{$\begin{array}{l}\text { Management } \\
\text { Plans }\end{array}$} & $\begin{array}{l}\text { May provide a } \\
\text { journal article or } \\
\text { formal feasibility } \\
\text { report }\end{array}$ & $\begin{array}{l}\text { May be a journal } \\
\text { article, additional } \\
\text { technical report, or } \\
\text { our proposal }\end{array}$ & $\begin{array}{l}\text { Project } \\
\text { Management } \\
\text { Plan }\end{array}$ & & & $\begin{array}{l}\text { Manufacturing } \\
\text { Plan (for TRL6 } \\
\text { and/or TRL7). }\end{array}$ \\
\hline & & & $\begin{array}{l}\text { Draft Systems } \\
\text { Engineering } \\
\text { Management } \\
\text { Plan }\end{array}$ & $\begin{array}{l}\text { Final Systems } \\
\text { Engineering } \\
\text { Management } \\
\text { Plan }\end{array}$ & & \multirow[t]{2}{*}{$\begin{array}{l}\text { Technology } \\
\text { Transition Plan }\end{array}$} \\
\hline & & & \multicolumn{2}{|c|}{$\begin{array}{l}\text { System Engineering Management } \\
\text { Plan (describing planned reviews, } \\
\text { planned processes, etc.) }\end{array}$} & & \\
\hline & & & $\begin{array}{l}\text { Draft } \\
\text { Technology } \\
\text { Maturation } \\
\text { Plan }\end{array}$ & $\begin{array}{l}\text { Final } \\
\text { Technology } \\
\text { Maturation Plan }\end{array}$ & & \multirow[t]{2}{*}{$\begin{array}{l}\text { Technology } \\
\text { Transition } \\
\text { Agreement }\end{array}$} \\
\hline & & & \multicolumn{2}{|c|}{$\begin{array}{l}\text { Technology Maturation Plan } \\
\text { (describing planned prototypes per } \\
\text { TRL, features supported, } \\
\text { fabrication methods, etc.) }\end{array}$} & & \\
\hline \multirow[t]{3}{*}{ Requirements } & \multirow[t]{2}{*}{ Constraints } & & Draft CONOPS & Final CONOPS & & \\
\hline & & & \multicolumn{2}{|c|}{$\begin{array}{l}\text { CONOPS (how device fits into } \\
\text { user organization and how it will } \\
\text { be used) }\end{array}$} & & \\
\hline & & $\begin{array}{l}\text { Begin to draft } \\
\text { operational } \\
\text { requirements }\end{array}$ & \begin{tabular}{|l} 
Operational \\
requirements \\
(describe \\
required \\
outcomes of \\
system actions \\
without \\
describing \\
system)
\end{tabular} & \begin{tabular}{|l|} 
System \\
Requirements \\
Specification, \\
functionality \\
(qualitative) and \\
performance \\
(quantitative) \\
requirements of \\
system
\end{tabular} & \begin{tabular}{|l|} 
Subsystem \\
Requirements \\
(software \\
requirements \\
for example)
\end{tabular} & \begin{tabular}{|l} 
System \\
Requirements \\
Specification \\
(update system \\
requirements \\
document after \\
validation that \\
requirements \\
satisfy user \\
needs)
\end{tabular} \\
\hline \multirow[t]{3}{*}{ Tests } & & & \begin{tabular}{|l|} 
Proof of \\
Concept \\
(results of \\
testing proof \\
model)
\end{tabular} & & & \\
\hline & & $\begin{array}{l}\text { Begin to draft } \\
\text { analysis of } \\
\text { alternatives }\end{array}$ & \multicolumn{2}{|c|}{$\begin{array}{l}\text { Analysis of alternatives (+/- of a } \\
\text { system using our tech vs. other } \\
\text { tech) }\end{array}$} & & \\
\hline & & & Test Strategy & \begin{tabular}{|l} 
Test Plan and \\
Test Report
\end{tabular} & $\begin{array}{l}\text { Test Plan and } \\
\text { Test Report }\end{array}$ & $\begin{array}{l}\text { Test Plan and } \\
\text { Test Report }\end{array}$ \\
\hline \multirow{5}{*}{$\begin{array}{l}\text { Formal } \\
\text { Reviews }\end{array}$} & & & \multicolumn{4}{|c|}{ Product Line Manager Project Review - can occur at any time } \\
\hline & & & & & \multicolumn{2}{|c|}{$\begin{array}{l}\text { Preliminary Design Review and } \\
\text { Critical Design Review ( TRL4- } \\
\text { TRL7) }\end{array}$} \\
\hline & \multicolumn{2}{|c|}{ “Has TRL been achieved?” } & \begin{tabular}{|l|} 
TRL3 \\
Assessment
\end{tabular} & \begin{tabular}{|l|} 
TRL4 \\
Assessment
\end{tabular} & \begin{tabular}{|l|} 
TRL5 \\
Assessment
\end{tabular} & \begin{tabular}{|l|} 
TRL6 \\
Assessment
\end{tabular} \\
\hline & & & & \begin{tabular}{|l|} 
Test Results \\
Review
\end{tabular} & \begin{tabular}{|l|} 
Test Results \\
Review
\end{tabular} & \begin{tabular}{|l} 
Test Results \\
Review
\end{tabular} \\
\hline & \multicolumn{2}{|c|}{ “Are we ready to enter next phase?” } & $\begin{array}{l}\text { Proof of } \\
\text { Concept Phase } \\
\text { Review }\end{array}$ & $\begin{array}{l}\text { Concept } \\
\text { Refinement } \\
\text { Phase Review }\end{array}$ & $\begin{array}{l}\text { Development } \\
\text { Phase Review }\end{array}$ & $\begin{array}{l}\text { Demonstration } \\
\text { and Transition } \\
\text { Phase Review }\end{array}$ \\
\hline
\end{tabular}




\section{Appendix C. Readiness Level Tables}

Table 5. TRL - General

\begin{tabular}{|c|c|c|}
\hline TRL & Description & Embodiment \\
\hline $\begin{array}{l}\text { 1. Basic principles } \\
\text { observed and } \\
\text { reported }\end{array}$ & $\begin{array}{l}\text { Lowest level of technology readiness. Scientific } \\
\text { research begins to be translated into applied research } \\
\text { and development. }\end{array}$ & $\begin{array}{l}\text { Analytical research (paper study, } \\
\text { computer or mathematical model) or } \\
\text { simple studies of basic properties in lab } \\
\text { setting. }\end{array}$ \\
\hline $\begin{array}{l}\text { 2. Technology } \\
\text { concept and/or } \\
\text { application } \\
\text { formulated }\end{array}$ & $\begin{array}{l}\text { Invention begins, practical applications can be } \\
\text { identified. Application is speculative with no proof } \\
\text { or detailed analysis to support assumption. } \\
\text { Examples are limited to paper studies. }\end{array}$ & $\begin{array}{l}\text { Paper studies and analysis of fit } \\
\text { between technology and application. }\end{array}$ \\
\hline $\begin{array}{l}\text { 3. Analytical and } \\
\text { experimental } \\
\text { critical function } \\
\text { and/or } \\
\text { characteristic } \\
\text { proof of concept }\end{array}$ & $\begin{array}{l}\text { Active research and development is initiated } \\
\text { including analytical and laboratory studies to } \\
\text { physically validate analytical predictions of separate } \\
\text { elements of the technology. Examples include } \\
\text { components that are not yet integrated or } \\
\text { representative. }\end{array}$ & $\begin{array}{l}\text { Analytical studies and demonstration of } \\
\text { nonscale individual components (pieces } \\
\text { of subsystem). Component developed } \\
\text { from new technology is supported by } \\
\text { lab apparatus and instrumentation in lab } \\
\text { setting. }\end{array}$ \\
\hline $\begin{array}{l}\text { 4. Component } \\
\text { and/or } \\
\text { breadboard } \\
\text { validation in } \\
\text { laboratory } \\
\text { environment }\end{array}$ & $\begin{array}{l}\text { Basic technological components are integrated to } \\
\text { establish that pieces will work together. Relatively } \\
\text { "low fidelity" compared to the eventual system. Not } \\
\text { fully functional or form or fit but representative of } \\
\text { technically feasible approach suitable for intended } \\
\text { application. Examples include integration of "ad- } \\
\text { hoc" hardware in a laboratory. }\end{array}$ & $\begin{array}{l}\text { Low-fidelity breadboard using new } \\
\text { technology with other system } \\
\text { components and additional lab } \\
\text { apparatus and instrumentation. } \\
\text { Integration of nonscale components to } \\
\text { show pieces work together in lab } \\
\text { environment. }\end{array}$ \\
\hline 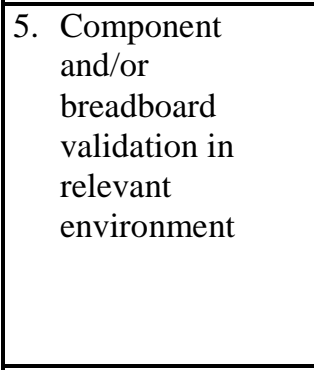 & $\begin{array}{l}\text { Fidelity of breadboard technology increases } \\
\text { significantly. Basic technological components are } \\
\text { integrated with reasonably realistic supporting } \\
\text { elements so that technology can be tested in relevant } \\
\text { environment (subsets of operational environment } \\
\text { simulated, as with environmental chambers or } \\
\text { operational mock-ups). Examples include "high- } \\
\text { fidelity” laboratory integration of components. }\end{array}$ & $\begin{array}{l}\text { High-fidelity breadboard. Functionally } \\
\text { equivalent but not necessarily form } \\
\text { and/or fit (size, weight, materials). } \\
\text { Should be approaching scale. May } \\
\text { include integration of several } \\
\text { components with reasonably realistic } \\
\text { support elements/subsystems to } \\
\text { demonstrate functionality in lab setting } \\
\text { with simulated relevant environment. }\end{array}$ \\
\hline $\begin{array}{l}\text { 6. System/ } \\
\text { subsystem model } \\
\text { or prototype } \\
\text { demonstration in } \\
\text { relevant } \\
\text { environment }\end{array}$ & $\begin{array}{l}\text { Representative model or prototype system that is } \\
\text { well beyond breadboard tested for TRL5 is tested in } \\
\text { relevant environment. Represents major step up in } \\
\text { demonstrated readiness. Examples include testing } \\
\text { prototype in high fidelity laboratory or simulated } \\
\text { operational environment. }\end{array}$ & $\begin{array}{l}\text { Prototype should be very close to form, } \\
\text { fit, and function of operational system. } \\
\text { Probably includes integration of new } \\
\text { components and realistic supporting } \\
\text { elements/subsystems if needed to } \\
\text { demonstrate full functionality. } \\
\text { Integration of technology is well } \\
\text { defined. High-fidelity lab } \\
\text { demonstration or limited/restricted field } \\
\text { demonstration for relevant } \\
\text { environment. }\end{array}$ \\
\hline $\begin{array}{l}\text { 7. System prototype } \\
\text { demonstration in } \\
\text { operational } \\
\text { environment }\end{array}$ & $\begin{array}{l}\text { Prototype near or at planned operational system. } \\
\text { Represents major step up from TRL6, requiring } \\
\text { demonstration of actual system prototype in } \\
\text { operational environment. Examples include testing } \\
\text { prototype in test bed aircraft. }\end{array}$ & $\begin{array}{l}\text { Prototype should be form, fit and } \\
\text { function integrated with other key } \\
\text { supporting elements/subsystems to } \\
\text { demonstrate full functionality of } \\
\text { subsystem in representative operational } \\
\text { environment. Technology is well } \\
\text { substantiated with test data. }\end{array}$ \\
\hline
\end{tabular}




\section{Table 6. DOD Hardware Based TRLs}

\begin{tabular}{|c|c|c|}
\hline TRL Definition & Description & Supporting Information \\
\hline $\begin{array}{l}\text { 1. } \begin{array}{l}\text { Basic principles } \\
\text { observed and } \\
\text { reported }\end{array} \\
\end{array}$ & $\begin{array}{l}\text { Lowest level of technology readiness. } \\
\text { Scientific research begins to be translated into } \\
\text { applied research and development. Examples } \\
\text { might include paper studies of a technology’s } \\
\text { basic properties. }\end{array}$ & $\begin{array}{l}\text { Published research identifying principles that underlie } \\
\text { technology. References to who, where, when. }\end{array}$ \\
\hline $\begin{array}{l}\text { Technology } \\
\text { concept and/or } \\
\text { application } \\
\text { formulated }\end{array}$ & $\begin{array}{l}\text { Once basic principles are observed, practical } \\
\text { applications can be invented. Applications } \\
\text { are speculative with no proof or detailed } \\
\text { analysis to support assumptions. Examples } \\
\text { are limited to analytic studies. }\end{array}$ & $\begin{array}{l}\text { Publications or other references that outline application } \\
\text { being considered and provide analysis to support the } \\
\text { concept. }\end{array}$ \\
\hline $\begin{array}{l}\text { 3. Analytical and } \\
\text { experimental } \\
\text { critical function } \\
\text { and/or } \\
\text { characteristic } \\
\text { proof of concept } \\
\end{array}$ & $\begin{array}{l}\text { Active research and development initiated } \\
\text { including analytical and laboratory studies to } \\
\text { physically validate analytical predictions of } \\
\text { separate elements. Examples include } \\
\text { components not yet integrated or } \\
\text { representative. }\end{array}$ & $\begin{array}{l}\text { Results of laboratory tests performed to measure } \\
\text { parameters of interest and comparison to analytical } \\
\text { predictions for critical subsystems. References to who, } \\
\text { where, and when tests and comparisons were performed. }\end{array}$ \\
\hline $\begin{array}{l}\text { 4. Component } \\
\text { and/or breadboard } \\
\text { validation in } \\
\text { laboratory } \\
\text { environment }\end{array}$ & $\begin{array}{l}\text { Basic technological components are } \\
\text { integrated to establish they work together. } \\
\text { Relatively "low fidelity" compared with } \\
\text { eventual system. Examples include } \\
\text { integration of “ad-hoc” hardware in } \\
\text { laboratory. }\end{array}$ & $\begin{array}{l}\text { System concepts considered and results from testing } \\
\text { laboratory-scale breadboard(s). References to who did } \\
\text { work and when. Provide estimate of how breadboard } \\
\text { hardware and test results differ from expected system } \\
\text { goals. }\end{array}$ \\
\hline $\begin{array}{l}\text { 5. Component and/ } \\
\text { or breadboard } \\
\text { validation in } \\
\text { relevant } \\
\text { environment }\end{array}$ & $\begin{array}{l}\text { Fidelity of breadboard technology increases } \\
\text { significantly. Basic technological } \\
\text { components are integrated with reasonably } \\
\text { realistic supporting elements to be tested in } \\
\text { simulated environment. Examples include } \\
\text { "high-fidelity” laboratory integration of } \\
\text { components. }\end{array}$ & $\begin{array}{l}\text { Results from testing laboratory breadboard system are } \\
\text { integrated with other supporting elements in simulated } \\
\text { operational environment. Describe how "relevant } \\
\text { environment” differs from expected operational } \\
\text { environment. How test results compare with } \\
\text { expectations. Problems encountered. How breadboard } \\
\text { system was refined to more nearly match expected goals. }\end{array}$ \\
\hline $\begin{array}{l}\text { 6. System/ } \\
\text { subsystem model } \\
\text { or prototype } \\
\text { demonstration in } \\
\text { relevant } \\
\text { environment } \\
\end{array}$ & $\begin{array}{l}\text { Representative model or prototype system that } \\
\text { is well beyond TRL5 is tested in relevant } \\
\text { environment. Represents major step up in } \\
\text { demonstrated readiness. Examples include } \\
\text { testing prototype in high-fidelity laboratory or } \\
\text { simulated operational environment. }\end{array}$ & $\begin{array}{l}\text { Results from laboratory testing of prototype system that } \\
\text { is near desired configuration in terms of performance, } \\
\text { weight, and volume. Describe how test environment } \\
\text { differs from operational environment. How tests } \\
\text { compare with expectations. Problems encountered and } \\
\text { options/ actions required before moving to next level. }\end{array}$ \\
\hline $\begin{array}{l}\text { 7. System prototype } \\
\text { demonstration in } \\
\text { operational } \\
\text { environment }\end{array}$ & $\begin{array}{l}\text { Prototype near or at planned operational } \\
\text { system. Represents major step up from TRL6 } \\
\text { by requiring demonstration of actual system } \\
\text { prototype in operational environment (e.g., } \\
\text { aircraft, vehicle, or in space). }\end{array}$ & $\begin{array}{l}\text { Results from testing a prototype system in an operational } \\
\text { environment. Who performed the tests? How did the } \\
\text { test compare with expectations? What problems, if any, } \\
\text { were encountered? What are/were the plans, options, or } \\
\text { actions to resolve problems before moving to the next } \\
\text { level? }\end{array}$ \\
\hline $\begin{array}{l}\text { 8. } \\
\text { completed and } \\
\text { qualified through } \\
\text { test and } \\
\text { demonstration }\end{array}$ & $\begin{array}{l}\text { Technology proven to work in final form and } \\
\text { under expected conditions. In most cases, } \\
\text { represents end of true system development. } \\
\text { Examples include developmental test and } \\
\text { evaluation to determine if system meets } \\
\text { design specifications. }\end{array}$ & $\begin{array}{l}\text { Results of testing system in final configuration under } \\
\text { expected range of environmental conditions. } \\
\text { Assessment of whether system meets operational } \\
\text { requirements. Problems encountered and plans, options, } \\
\text { or actions to resolve problems before finalizing design. }\end{array}$ \\
\hline $\begin{array}{l}\text { 9. Actual system } \\
\text { proven through } \\
\text { successful } \\
\text { mission } \\
\text { operations }\end{array}$ & $\begin{array}{l}\text { Actual application of technology in final form } \\
\text { and under mission conditions, such as } \\
\text { encountered in operational test and } \\
\text { evaluation. }\end{array}$ & Test and evaluation reports. \\
\hline
\end{tabular}


Table 7. DOD Software Based TRLs

\begin{tabular}{|c|c|c|}
\hline TRL Definition & Description & Supporting Information \\
\hline $\begin{array}{l}\text { 1. Basic principles } \\
\text { observed and } \\
\text { reported }\end{array}$ & $\begin{array}{l}\text { Lowest level of software technology readiness. New } \\
\text { software domain is investigated by basic research } \\
\text { community. Level extends to development of basic use, } \\
\text { basic properties of software architecture, mathematical } \\
\text { formulations, and general algorithms. }\end{array}$ & $\begin{array}{l}\text { Basic research activities, research articles, } \\
\text { peer-reviewed white papers, point papers, } \\
\text { early lab model of basic concept may be } \\
\text { useful for substantiating TRL. }\end{array}$ \\
\hline $\begin{array}{l}\text { Technology } \\
\text { concept and/or } \\
\text { application } \\
\text { formulated } \\
\end{array}$ & $\begin{array}{l}\text { Once basic principles observed, practical applications can } \\
\text { be invented. Applications are speculative with no proof } \\
\text { or detailed analysis to support assumptions. Examples are } \\
\text { limited to analytic studies using synthetic data. }\end{array}$ & $\begin{array}{l}\text { Applied research activities, analytic studies, } \\
\text { small code units, and papers comparing } \\
\text { competing technologies. }\end{array}$ \\
\hline $\begin{array}{l}\text { 3. Analytical and } \\
\text { experimental } \\
\text { critical function } \\
\text { and/or } \\
\text { characteristic } \\
\text { proof of concept } \\
\end{array}$ & $\begin{array}{l}\text { Active research and development initiated. Level of } \\
\text { scientific feasibility is demonstrated through analytical } \\
\text { and laboratory studies. Extends to development of limited } \\
\text { functionality environments to validate critical properties } \\
\text { and analytical predictions using non-integrated software } \\
\text { components and partially representative data. }\end{array}$ & $\begin{array}{l}\text { Algorithms run on surrogate processor in } \\
\text { laboratory environment, instrumented } \\
\text { components operating in laboratory } \\
\text { environment, laboratory results showing } \\
\text { validation of critical properties. }\end{array}$ \\
\hline $\begin{array}{l}\text { 4. Module and/or } \\
\text { subsystem } \\
\text { validation in } \\
\text { laboratory } \\
\text { environment }\end{array}$ & $\begin{array}{l}\text { Basic software components integrated to establish they } \\
\text { work together. Relatively primitive with regard to } \\
\text { eventual system. Architecture development initiated to } \\
\text { include interoperability, reliability, maintainability, } \\
\text { extensibility, scalability, and security issues. Emulation } \\
\text { with current/legacy elements as appropriate. Prototypes } \\
\text { developed to demonstrate different aspects of system. }\end{array}$ & $\begin{array}{l}\text { Advanced technology development, stand- } \\
\text { alone prototype solving synthetic full-scale } \\
\text { problem, or stand-alone prototype processing } \\
\text { fully representative data sets. }\end{array}$ \\
\hline $\begin{array}{l}\text { 5. } \text { Module and/or } \\
\text { subsystem } \\
\text { validation in } \\
\text { relevant } \\
\text { environment }\end{array}$ & $\begin{array}{l}\text { Software technology ready to start integration with } \\
\text { existing systems. Prototype implementations conform to } \\
\text { target environment/interfaces. Experiments with realistic } \\
\text { problems. Simulated interfaces to existing systems. } \\
\text { System software architecture established. Algorithms run } \\
\text { on processor(s) with characteristics expected in } \\
\text { operational environment. }\end{array}$ & $\begin{array}{l}\text { System architecture diagram around } \\
\text { technology element with critical performance } \\
\text { requirements defined. Processor selection } \\
\text { analysis, simulation/stimulation laboratory } \\
\text { buildup plan. Software placed under } \\
\text { configuration management. COTS/ } \\
\text { government furnished components identified. }\end{array}$ \\
\hline $\begin{array}{l}\text { 6. } \\
\text { sodule and/or } \\
\text { validation in } \\
\text { relevant end-to- } \\
\text { end environment }\end{array}$ & $\begin{array}{l}\text { Level at which engineering feasibility of software } \\
\text { technology is demonstrated. Extends to laboratory } \\
\text { prototype implementations on full-scale realistic problems } \\
\text { in which software technology is partially integrated with } \\
\text { existing hardware/software systems. }\end{array}$ & $\begin{array}{l}\text { Results from laboratory testing of prototype } \\
\text { package that is near desired configuration in } \\
\text { terms of performance, including physical, } \\
\text { logical, data, and security interfaces. } \\
\text { Comparisons between tested and operational } \\
\text { environment analytically understood. } \\
\text { Results quantifying contribution to system- } \\
\text { wide requirements such as throughput, } \\
\text { scalability, and reliability. Analysis of } \\
\text { human-computer (user environment) begun. }\end{array}$ \\
\hline $\begin{array}{l}\text { 7. System prototype } \\
\text { demonstration in } \\
\text { operational high- } \\
\text { fidelity } \\
\text { environment }\end{array}$ & $\begin{array}{l}\text { Level at which program feasibility of software technology } \\
\text { is demonstrated. Extends to operational environment } \\
\text { prototype implementations where critical technical risk } \\
\text { functionality is available for demonstration and a test in } \\
\text { which software technology is well integrated with } \\
\text { operational hardware/software systems. } \\
\end{array}$ & $\begin{array}{l}\text { Critical technological properties measured } \\
\text { against requirements in operational } \\
\text { environment. }\end{array}$ \\
\hline $\begin{array}{l}\text { 8. Actual system } \\
\text { completed and } \\
\text { mission qualified } \\
\text { through test and } \\
\text { demonstration in } \\
\text { operational } \\
\text { environment } \\
\end{array}$ & $\begin{array}{l}\text { Level at which software technology is fully integrated } \\
\text { with operational hardware and software systems. } \\
\text { Software development documentation is complete. All } \\
\text { functionality tested in simulated and operational } \\
\text { scenarios. }\end{array}$ & $\begin{array}{l}\text { Published documentation and product } \\
\text { technology refresh build schedule. Software } \\
\text { resource reserve measured and tracked. }\end{array}$ \\
\hline $\begin{array}{l}\text { 9. Actual system } \\
\text { proven through } \\
\text { successful } \\
\text { mission-proven } \\
\text { operational } \\
\text { capabilities } \\
\end{array}$ & $\begin{array}{l}\text { Level at which software technology is readily repeatable } \\
\text { and reusable. Software based on technology is fully } \\
\text { integrated with operational hardware/software systems. } \\
\text { All software documentation verified. Successful } \\
\text { operational experience. Sustaining software engineering } \\
\text { support in place. Actual system. }\end{array}$ & $\begin{array}{l}\text { Production configuration management } \\
\text { reports. Technology integrated into a reuse } \\
\text { "wizard.” }\end{array}$ \\
\hline
\end{tabular}




\section{Table 8. Additional TRL Definitions}

\begin{tabular}{|l|l|}
\hline \multicolumn{1}{|c|}{ Term } & \multicolumn{1}{c|}{ Definition } \\
\hline Breadboard & $\begin{array}{l}\text { Integrated components that provide a representation of a system/subsystem and that can be used } \\
\text { to determine concept feasibility and develop technical data. Typically configured for laboratory } \\
\text { use to demonstrate the technical principles of immediate interest. May resemble final } \\
\text { system/subsystem in function only. }\end{array}$ \\
\hline High Fidelity & $\begin{array}{l}\text { Addresses form, fit, and function. A high-fidelity laboratory environment would involve testing } \\
\text { with equipment that can simulate and validate all system specifications within a laboratory } \\
\text { setting. }\end{array}$ \\
\hline Low Fidelity & $\begin{array}{l}\text { Representative of the component or system that has limited ability to provide anything but first- } \\
\text { order information about end product. Low-fidelity assessments are used to provide trend } \\
\text { analysis. }\end{array}$ \\
\hline Model & $\begin{array}{l}\text { Functional form of system, generally reduced in scale, near or at operational specification. } \\
\text { Models will be sufficiently hardened to allow demonstration of technical and operational } \\
\text { capabilities required of final system. }\end{array}$ \\
\hline $\begin{array}{l}\text { Operational } \\
\text { Environment }\end{array}$ & $\begin{array}{l}\text { Environment that addresses all operational requirements and specifications required of final } \\
\text { system to include platform/packaging. }\end{array}$ \\
\hline Prototype & $\begin{array}{l}\text { Physical or virtual model used to evaluate technical or manufacturing feasibility or military utility } \\
\text { of a particular technology or process, concept, end item, or system. }\end{array}$ \\
\hline $\begin{array}{l}\text { Relevant } \\
\text { Environment }\end{array}$ & $\begin{array}{l}\text { Testing environment that simulates both most important and most stressing aspects of operational } \\
\text { environment. }\end{array}$ \\
\hline $\begin{array}{l}\text { Simulated } \\
\text { Operational } \\
\text { Environment }\end{array}$ & $\begin{array}{l}\text { Either (1) a real environment that can simulate all operational requirements and specifications } \\
\text { required of final system or (2) a simulated environment that allows testing of virtual prototype. } \\
\text { Used in either case to determine whether developmental system meets operational requirements } \\
\text { and specifications of final system. }\end{array}$ \\
\hline
\end{tabular}


Table 9. Manufacturing and Technology Readiness Levels

\begin{tabular}{|c|c|c|}
\hline TRL Definition & MRL Definition & MRL Description \\
\hline $\begin{array}{l}\text { 1. } \begin{array}{l}\text { Basic principles } \\
\text { observed and } \\
\text { reported }\end{array} \\
\end{array}$ & $\begin{array}{l}\text { 1. Basic manufacturing } \\
\text { implications identified }\end{array}$ & $\begin{array}{l}\text { Lowest level of manufacturing readiness. Focus is to address manufacturing } \\
\text { shortfalls and opportunities needed to achieve program objectives. Basic } \\
\text { research begins as studies. }\end{array}$ \\
\hline $\begin{array}{l}\text { 2. Technology } \\
\text { concept and/or } \\
\text { application } \\
\text { formulated }\end{array}$ & $\begin{array}{l}\text { 2. } \text { Manufacturing } \\
\text { concepts identified }\end{array}$ & $\begin{array}{l}\text { Applied research translates basic research into solutions for broadly defined } \\
\text { military needs. This level of readiness in science and technology environment } \\
\text { includes identification, paper studies, and analysis of material and process } \\
\text { approaches. Understanding of manufacturing feasibility and risk is emerging. }\end{array}$ \\
\hline 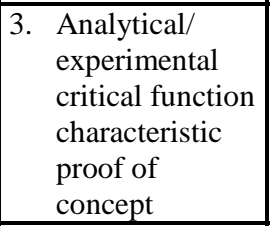 & $\begin{array}{l}\text { 3. Manufacturing proof } \\
\text { of concept developed }\end{array}$ & $\begin{array}{l}\text { Validation of the manufacturing concepts begins through analytical or } \\
\text { laboratory experiments. Materials and/or processes have been characterized } \\
\text { for manufacturability and availability but further evaluation and demonstration } \\
\text { is required. Experimental hardware models developed in laboratory } \\
\text { environment may possess limited functionality. }\end{array}$ \\
\hline 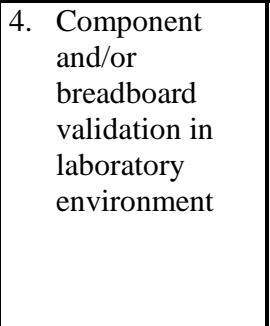 & $\begin{array}{l}\text { 4. Capability to produce } \\
\text { technology in } \\
\text { laboratory } \\
\text { environment }\end{array}$ & $\begin{array}{l}\text { Technologies have matured to TRL4. Required investments, such as } \\
\text { manufacturing technology development, have been identified. Processes to } \\
\text { ensure manufacturability and quality are in place and sufficient to produce } \\
\text { technology demonstrators. Manufacturing risks have been identified for } \\
\text { building prototypes and mitigation plans are in place. Target cost objectives } \\
\text { are established and manufacturing cost drivers identified. Manufacturability } \\
\text { assessments of design concepts have been completed. Key design } \\
\text { performance parameters are identified as well as any special tooling, facilities, } \\
\text { material handling, and skills required. }\end{array}$ \\
\hline $\begin{array}{l}\text { 5. } \\
\text { and/ or } \\
\text { breadboard } \\
\text { validation in } \\
\text { relevant } \\
\text { environment }\end{array}$ & $\begin{array}{l}\text { 5. Capability to produce } \\
\text { prototype components } \\
\text { in production-relevant } \\
\text { environment }\end{array}$ & $\begin{array}{l}\text { Technologies have matured to TRL5. Industrial base has been assessed to } \\
\text { identify potential manufacturing sources. Manufacturing strategy is refined } \\
\text { and integrated with risk management plan. Identification of enabling/critical } \\
\text { technologies and components are complete. Prototype materials, tooling, and } \\
\text { test equipment as well as personnel skills have been demonstrated on } \\
\text { components in production-relevant environment, but many manufacturing } \\
\text { processes and procedures are still in development. Manufacturing technology } \\
\text { development efforts are initiated or ongoing. Manufacturability assessments } \\
\text { of key technologies and components are ongoing. Cost model has been } \\
\text { constructed to assess projected manufacturing cost. }\end{array}$ \\
\hline \begin{tabular}{|l} 
6. \\
System/ \\
subsystem \\
model or \\
prototype \\
demonstration \\
in relevant \\
environment
\end{tabular} & $\begin{array}{l}\text { 6. Capability to produce } \\
\text { prototype system or } \\
\text { subsystem in } \\
\text { production-relevant } \\
\text { environment }\end{array}$ & $\begin{array}{l}\text { MRL associated with readiness for decision to initiate acquisition program by } \\
\text { entering into engineering and manufacturing development phase of } \\
\text { acquisition. Technologies have matured to TRL6. Normally seen as level of } \\
\text { manufacturing readiness that denotes completion of science and technology } \\
\text { development and acceptance into preliminary system design. Initial } \\
\text { manufacturing approach has been developed. Majority of manufacturing } \\
\text { processes are defined and characterized, but there may be significant } \\
\text { engineering and/or design changes in system. Preliminary design of critical } \\
\text { components and manufacturability assessments of key technologies are } \\
\text { complete. Prototype materials, tooling, and test equipment as well as } \\
\text { personnel skills have been demonstrated on systems and/or subsystems in } \\
\text { production-relevant environment. Cost analysis has been performed to assess } \\
\text { projected manufacturing cost versus target cost objectives and program has } \\
\text { appropriate risk reduction to achieve cost requirements or establish new } \\
\text { baseline. Analysis should include design trades. Manufacturability } \\
\text { considerations have shaped system development plans. Long-lead and key } \\
\text { supply chain elements have been identified. }\end{array}$ \\
\hline $\begin{array}{l}\text { 7. System } \\
\text { prototype } \\
\text { demonstration } \\
\text { in operational } \\
\text { environment }\end{array}$ & $\begin{array}{l}\text { 7. Capability to produce } \\
\text { systems, subsystems, } \\
\text { or components in } \\
\text { production- } \\
\text { representative } \\
\text { environment }\end{array}$ & $\begin{array}{l}\text { Manufacturing readiness is typical for midpoint of engineering and } \\
\text { manufacturing development phase. Technologies on path to achieve TRL7. } \\
\text { System detailed design activity is underway. Material specifications are } \\
\text { approved and materials available to meet planned pilot line build schedule. } \\
\text { Manufacturing processes and procedures have been demonstrated in } \\
\text { production-representative environment. Detailed manufacturability trade } \\
\text { studies and risk assessments are underway. Cost model updated with detailed } \\
\text { designs, rolled up to system level, and tracked against allocated targets. Unit } \\
\text { cost reduction efforts are prioritized and underway. Supply chain and supplier }\end{array}$ \\
\hline
\end{tabular}




\begin{tabular}{|c|c|c|}
\hline TRL Definition & MRL Definition & MRL Description \\
\hline & & $\begin{array}{l}\text { quality assurance have been assessed and long-lead procurement plans are in } \\
\text { place. Production tooling and test equipment design and development have } \\
\text { been initiated. }\end{array}$ \\
\hline 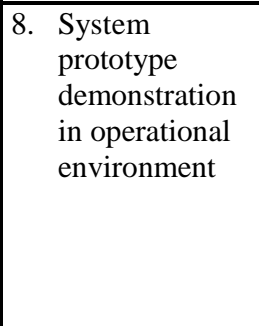 & $\begin{array}{l}\text { 8. Pilot line capability } \\
\text { demonstrated; ready } \\
\text { to begin low-rate } \\
\text { initial production }\end{array}$ & $\begin{array}{l}\text { Readiness for entry into low-rate initial production. Technologies have } \\
\text { matured to TRL7. Detailed system design essentially complete and } \\
\text { sufficiently stable to enter low-rate production. All materials are available to } \\
\text { meet planned low-rate production schedule. Manufacturing and quality } \\
\text { processes and procedures have been proven in pilot line environment and are } \\
\text { under control and ready for low-rate production. Known manufacturability } \\
\text { risks pose no significant challenges for low-rate production. Engineering cost } \\
\text { model driven by detailed design and validated with actual data. Supply chain } \\
\text { is established and stable. }\end{array}$ \\
\hline 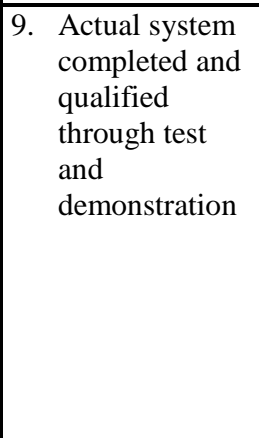 & $\begin{array}{l}\text { 9. Low-rate production } \\
\text { demonstrated; } \\
\text { capability in place to } \\
\text { begin full-rate } \\
\text { production }\end{array}$ & $\begin{array}{l}\text { System, component, or item was previously produced, is in production, or has } \\
\text { successfully achieved low-rate initial production. Technologies have matured } \\
\text { to TRL9. Normally associated with readiness for entry into full-rate } \\
\text { production. All systems engineering/design requirements have been met such } \\
\text { that there are minimal system changes. Major system design features are } \\
\text { stable and proven in test and B4 evaluation. Materials are available to meet } \\
\text { planned rate production schedules. Manufacturing process capability in low- } \\
\text { rate production environment at appropriate quality level to meet design key } \\
\text { characteristic tolerances. Production risk monitoring is ongoing. Low-rate } \\
\text { initial production cost targets have been met and learning curves analyzed } \\
\text { with actual data. Cost model has been developed for full-rate production } \\
\text { environment and reflects impact of continuous improvement. }\end{array}$ \\
\hline $\begin{array}{l}\text { 10. Actual system } \\
\text { proven through } \\
\text { successful } \\
\text { mission } \\
\text { operations }\end{array}$ & $\begin{array}{l}\text { 10. Full-rate production } \\
\text { demonstrated and lean } \\
\text { production practices } \\
\text { in place }\end{array}$ & $\begin{array}{l}\text { Highest level of production readiness. Technologies matured to TRL9. } \\
\text { Normally associated with the production or sustainment phases of acquisition } \\
\text { lifecycle. Engineering/design changes are few and generally limited to quality } \\
\text { and cost improvements. System, components, or items are in full-rate } \\
\text { production and meet all engineering, performance, quality, and reliability } \\
\text { requirements. Manufacturing process capability is at appropriate quality level. } \\
\text { All materials, tooling, inspection and test equipment, facilities, and manpower } \\
\text { are in place and have met full-rate production requirements. Unit costs meet } \\
\text { goals and funding is sufficient for production at required rates. Lean practices } \\
\text { are well established and continuous process improvements are ongoing. }\end{array}$ \\
\hline
\end{tabular}




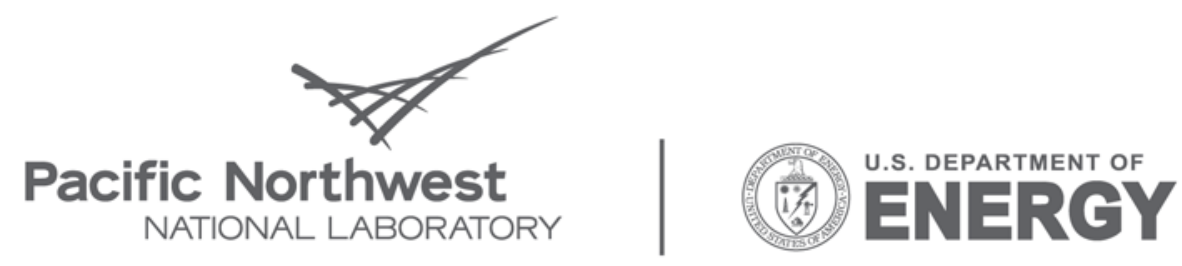

Proudly Operated by Battelle Since 1965

902 Battelle Boulevard

P.O. Box 999

Richland, WA 99352

1-888-375-PNNL (7665)

www.pnl.gov 